\title{
PERAN SERTA PEREMPUAN DALAM PENYELENGGARAAN PEMERINTAHAN DESA BANJARSARI KECAMATAN/KABUPATEN MADIUN
}

\author{
Muhammad Hanif*
}

\begin{abstract}
Abstrak
Penelitian ini bertujuan untuk mendapatkan gambaran tentang peran serta perempuan dalam penyelenggaraan pemerintahan Desa Banjarsari Kecamatan/ Kabupaten Madiun.Penelitian dilakukan selama enam bulan di Desa Banjarsari Kecamatan/ Kabupaten Madiun Provinsi Jawa Timur. Sumber datanya berupa primer dan skunder. Penentuan informannya dengan purposive sampling dan pengambilan datanya menggunakan wawancara, observasi, dan pencatatan dokumen. Data yang diperoleh dianalisa dengan analisis kualititatif model interaktif.

Dari penelitian yang dilakukan diperoleh gambaran, bahwa pemerintahan desa Banjarsari memberi peluang bagi perempuan untuk dapat terlibat secara langsung namun belum banyak dimanfaatkan. Hanya 84 orang yang berperan secara aktif dalam lembaga pemerintahan desa dan 10 orang yang menjadi pengurus partai politik dari jumlah perempuan 1.538 orang. Hal tersebut dikarenakan belum adanya kesadaran kritis atas hak-haknya untuk mengaktualisasikan dirinya. Selain itu masih banyak perempuan yang beranggapan, bahwa urusan perempuan adalah soal rumah-tangga dan hanya peran skunder. Politik adalah urusan laki-laki, politik itu kotor, politik itu keras sehingga perempuan tidak perlu ambil bagian. Pandangan ini dipengaruhi oleh faktor budaya patriarkhi, beban kerja yang lebih besar dibandingkan dengan laki-laki, dan tingkat ekonominya. Walaupun sebagian kecil kaum perempuan yang berada dalam lembaga pemerintahan desa namun mereka dapat memainkan peran yang tidak kalah pentingnya bila dibandingkan dengan kaum laki-laki.
\end{abstract}

\section{Kata Kunci : Perempuan, Penyelenggaraan Pemerintahan Desa}

\section{Pendahuluan}

Bergesernya

konfigurasi

kekuatan politik yang ditandai dengan lahirnya era reformasi memberikan implikasi serius terhadap dinamika politik di pedesaan. Apa yang terjadi di Jakarta memberi pengaruh yang signifikan terhadap kehidupan politik, sosial, dan ekonomi desa. Khusus dalam bidang politik ditandai dengan adanya perubahan ruang politik yang memberi tempat dan harga pada massa-rakyat (masyarakat) sebagai upaya membangun demokrasi sampai ke akar rumput (desa). Sehingga kehidupan masyarakat tidak lagi dalam cenkraman otoriterisme (anti demokrasi) dan jauh dari harapan rakyat (Christina dkk.2001). Perubahan tata politik sebagaimana dimaksud di atas dibuktikan adanya kebijakan desentralisasi melalui Undang Undang Nomor 22 Tahun 1999 tentang Otonomi Daerah. 
Otonomi daerah sudah lama dibicarakan dengan berbagai sudut pandang, namun ada satu hal yang patut diperhatikan dan hampir terlupakan dalam setiap pembahasannya adalah masalah perempuan. Sebagaimana yang disampaikan Christina M (2001), walaupun perempuan menjadi kelompok masyarakat yang lebih besar jumlahnya dibandingkan laki-laki, namun pembicaraan dan perhatian terhadap perempuan ini masih sedikit atau nyaris tidak ada.

Keprihatinan terhadap masalah tersebut di atas perlu direspon dengan mengangkat setiap permasalahan yang dialami oleh perempuan. Satu diantaranya yang menarik adalah peran serta perempuan dalam penyelenggaraan pemerintahan desa. Seperti disinggung di dalam Undang Undang Nomor 22 Tahun 1999, peran serta masyarakat sangat terbuka luas, mulai dari pembentukan, penghapusan dan atau penggabungan desa sampai dengan proses pengambilan keputusan untuk pembangunan dan kepentingan komunitas desa atau penyelenggaraan pemerintahan desa. Disinilah perlunya peran serta masyarakat yang lebih nyata untuk turut mengambil keputusan dan kontrol terhadap penyelenggaraan pemerintahan desa. Artinya ada akses dan kesempatan yang sama bagi setiap elemen masyarakat untuk berperan serta dalam politik desa.. Tidak ada perbedaan suku, agama, ras, dan jenis kelamin.

Dengan demikian demokratisasi desa memberi ruang luas keterlibatan bagi kaum perempuan untuk berkiprah. Namun bagaimana realitanya ? inilah yang mendorong penelitian ini dilakukan dengan mengambil kasus di Desa Banjarsari Kecamatan Madiun Kabupaten Madiun. Dipilihnya desa ini sebagai subyek penelitian karena desa ini tergolong dinamis dan masyarakatnya "melek politik". Salah satunya ditandai dengan adanya 10 parpol yang mempunyai organisasi ranting di desa ini. Selain itu masyarakatnya secara mayoritas berpendidikan dan sarana komunikasi dan informasi relatif mudah diperoleh , baik melalui media cetak maupun elektronik. Dalam situasi dan kondisi seperti ini menarik untuk diteliti tentang keberadaan dan kiprah kaum perempuan yang permasalannya dapat dirumuskan ; bagaimanakah peran serta perempuan dalam penyelenggaraan pemerintahan desa di Desa Banjarsari Kecamatan Madiun Kabupaten Madiun? Penelitian ini dilaksanakan bertujuan untuk mendapatkan gambaran secara komprehensif peran serta perempuan dalam penyelenggaraan pemerintahan Desa Banjarsari Kecamatan / Kabupaten 
Madiun. Hasil penelitian ini diyakini dapat bermanfaat bagi berbagai pihak, diantaranya : 1). Bagi Program Studi Pendidikan sejarah FPIPS IKIP PGRI Madiun, hasil penelitian ini akan sangat berguna dalam pengajaran sejarah kontemporer dan sejarah lokal. 2). Bagi masyarakat, terutama para perempuan, penelitian ini dapat memberikan gambaran tentang gender dan tranformasi nilai, serta dimungkinkan dapat meningkatkan kesadaran sejarah. 3). Bagi pemerintah, khususnya Pemerintah Daerah dapat dijadikan bahan untuk mengambil kebijakan dalam pembangunan baik fisik maupun mental, terutama yang berkaitan dengan masalah gender.

\section{Tinjauan Pustaka}

Peran serta politik perempuan dapat dilihat dari sudut pandang transformasi perempuan yang mencakup fungsionalisme dalam feminisme (Fakih.2003). Selain itu dapat dilihat juga dari sudut pandang gender specifity yaitu mencakup pola-pola perilaku, ekspresi emosional yang secara sosial dapat dipelajari serta digunakan untuk menilai tingkat keperempuannya dan kepribadian seseorang (Tangdilintin.1991). Sedangkan Barker (2004) menyatakan, bahwa aktivitas ini mengarah pada suatu gerakan untuk mengkonstruksi strategi politik yang digunakan untuk melakukan intervensi kedalam kehidupan demi mengabdi kepada kepentingan perempuan.

Pola-pola perilaku maupun ekspresi emosional perempuan dapat terungkap melalui tersedia jejak, baik yang bersifat materiil dan non materiil. Sumber peristiwa yang bersifat materiil diantaranya ; prasasti, laporan tertulis, dan sebagainya. Sedangkan yang bersifat non materiil diantaranya ; lembaga sosial, etik, tradisi, dan sebagainya. Dengan pengecekan secara kritis sumber sejarah tersebut di atas akan membuka wawasan di dalam melihat peranan perempuan. Hal senada disampaikan Sendratari (1992), bahwa gambaran perempuan dapat digali lewat dokumen dan kesaksian pelaku peristiwa.

Menurut Undang Undang Nomor 32 tahun 2004 mengenai Pemerintahan Daerah dan Peraturan Pemerintah Pengganti Undang-Undang Nomor 3 Tahun 2005 tentang Perubahan Atas Undang-Undang Nomor 32 Tahun 2004 tentang Pemerintahan Daerah yang memposisikan desa sebagai wilayah otonom, maka secara politis desa mempunyai posisi tawar yang cukup kuat, naik ketika berhadapan dengan pemerintah kabupaten, pusat, maupun terhadap kepentingan dari luar desa 
(Yam'ah Tsalata A.2001). Hal tersebut akan berjalan secara optimal bila peran rakyat lebih nyata untuk turut mengambil keputusan dan melakukan kontrol terhadap penyelenggaraan pemerintahan desa. Dalam undangundang tersebut ada klausul penting, yakni perubahan kebijakan mengenai desa yang didalamnya memuat kebijakan untuk merombak sistem politik di tingkat desa, dengan menghadirkan parlemen desa (Suhartono.2000).

Ada beberapa alternatif tempat strategis yang relevan bagi perempuan untuk berperan serta dalam politik desa. Menurut Sari Murti W. (2001) ada tiga hal yaitu : Pertama, perempuan perlu melibatkan diri ke dalam partai politik sebagai pintu masuk ke posisi legislatif (Badan Perwakilan Desa / BPD) dan eksekutif. Kedua, posisi sebagai tokoh masyarakat, sehingga bisa menjadi saluran aspirasi masyarakat. Dengan demikian setiap usaha pembangunan dapat dikendalikan dari perencanaan sampai dengan pelaksanaannya agar kepentingan perempuan tidak terabaikan. Ini berarti sekaligus akan merubah paradigma perempuan sebagai obyek pembangunan berubah menjadi subyek pembangunan. Ketiga, memposisikan diri sebagai kelompopk penekan (pressure group). Sangat cocok bagi perempuan biasa-biasa saja namunpunya komitmen yang tinggi untuk senantiasa melaksanakan kebaikan bersama. Dengan demikian sangat terbuka bagi perempuan memainkan perannya dalam penyelenggaraan pemerintahan desa. Namun demikian tidak serta merta peluang ini dimanfaatkan oleh perempuan karena bagi perempuan pada umumnya, politik dianggap urusan laki-laki, politik kotor, politik itu keras sehingga perempuan tidak perlu terlibat didalamnya. Pandangan seperti itu membuat tidak banyak perempuan yang terjun ke politik, walaupun secara yuridis formal hak-hak itu itu diakui (Undang Undang Nomor 39 Tahun 1999).

\section{Metode Penelitian}

Penelitian ini menggunakan Metode Hermenutika-Mendalam Thomson (Thomson.2004). Dipilihnya metode karena penelitian tidak hanya serentetan objek dan peristiwa yang akan diteliti dan dijelaskan, tetapi juga domain subjek yang dirancang sebagai subjek yang dalam rutinitas kehidupan sehari-harinya, secara konstan berada dalam pemahaman dirinya dan orang lain dalam menghasilkan tindakan dan ekspresi yang bermakna serta dalam menafsirkan tindakan dan ekspresi yang bermakna yang dilakukan oleh orang lain.Penelitian ini dilakukan di Desa Banjarsari Kecamatan Madiun Kabupaten 
Madiun. Sedangkan waktu penelitian mulai bulan Juli sampai dengan Desember 2012. Sumber data yang digunakan dalam penelitian ini : sumber primer dan skunder. Sumber primer diantaranya ; sumber lisan/ kesaksian, laporan tertulis, dan dokumen. Sedangkan yang skunder diantaranya ; lembaga sosial, etik, dan tradisi. Informan penelitian ditentuakan secara area (dukuh/dusun). Sedangkan pengambilan data penelitiannya menggunakan teknik wawancara, observasi, dan pencatatan dokumen. Dalam menganalisa data, peneliti menggunakan analisis kualititatif model interaktif (Milles.1992) sebagaimana bagan dibawah ini:

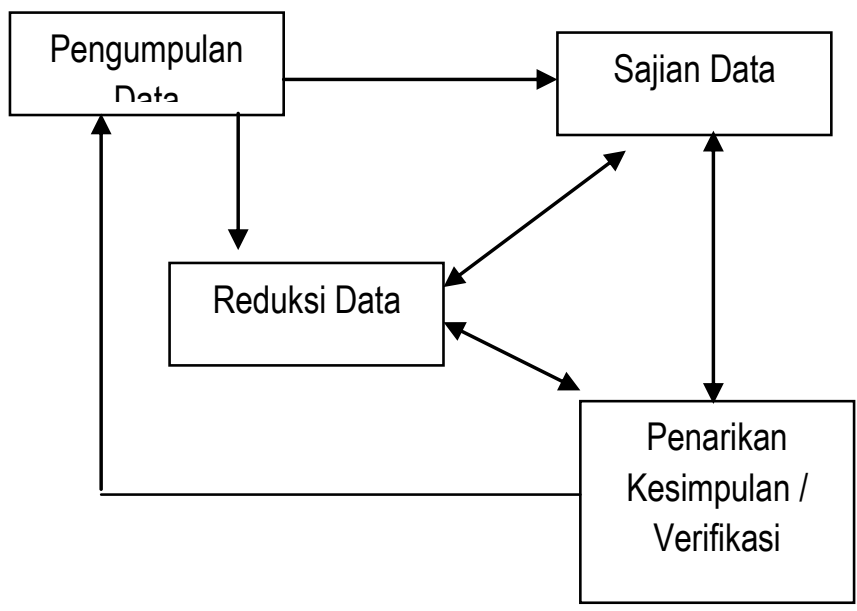

Bagan 1 : Analisis Kualitatif Model Interaktif

\section{Hasil Penelitian}

\section{Gambaran Singkat Desa Banjarsari}

Desa Banjarsari merupakan salah satu desa di Kecamatan Madiun Kabupaten Madiun dengan luas wilayah 295,149 $\mathrm{m}^{2}$. Batas-batas wilayahnya sebagai berikut:
- Sebelah Utara: Desa Garon Kecamatan Balerejo Kabupaten Madiun

- Sebelah Timur: Desa Sumberejo Kecamatan Madiun Kabupaten Madiun

- Sebelah Selatan : Desa Kelun Kecamatan Kartoharjo Kota Madiun

- Sebelah Barat: Desa Tiron Kecamatan Madiun Kabupaten Madiun

Sedangkan orbitasinya (jarak dari pusat pemerintahan) sebagainya :

- Jarak dari pusat pemerintahan kecamatan: $4 \mathrm{~km}$

-Jarak dari pusat pemerintahan kota kabupaten: $10 \mathrm{~km}$

-Jarak dari pusat pemerintahan propinsi: $170 \mathrm{~km}$

- Jarak dai pusat pemerintahan negara:1.500 $\mathrm{km}$.

Kondisi geografis Desa Banjarsari berada pada $36 \mathrm{~m}$ dari ketinggian permukaan air laut, termasuk dataran rendah dengan suhu udaranya rata-rata $32^{\circ} \mathrm{C}$. Demografisnya berjumlah 3.028 orang yang terdiri jenis kelamin sebagai berikut:

Tabel 2 : Jumlah Penduduk Berdasarkan Jenis Kelamin

\begin{tabular}{|c|l|r|}
\hline No & \multicolumn{1}{|c|}{$\begin{array}{c}\text { Tingkat } \\
\text { Pendidikan }\end{array}$} & Jumlah \\
\hline 1 & Laki-laki & $\begin{array}{r}1.490 \\
\text { Orang }\end{array}$ \\
\hline 2 & Perempuan & $\begin{array}{r}1.538 \\
\text { Orang }\end{array}$ \\
\hline & Jumlah & $\begin{array}{r}3.028 \\
\text { Orang }\end{array}$ \\
\hline
\end{tabular}

(Monografi Desa Banjarsari)

Apabila dilihat berdasarkan tingkat pendidikannya dapat diklasifikasikan sebagai berikut : 
Tabel 3 : Jumlah Penduduk Berdasarkan Tingkat Pendidikan

\begin{tabular}{|c|l|r|}
\hline No & \multicolumn{1}{|c|}{$\begin{array}{c}\text { Tingkat } \\
\text { Pendidikan }\end{array}$} & Jumlah \\
\hline 1 & $\begin{array}{l}\text { Taman Kanak- } \\
\text { kanak / PAUD }\end{array}$ & 57 Orang \\
\hline 2 & Sekolah Dasar & $\begin{array}{r}1.058 \\
\text { Orang }\end{array}$ \\
\hline 3 & SLTP & 629 Orang \\
\hline 4 & SLTA & 474 Orang \\
\hline 5 & Diploma & 48 Orang \\
\hline 6 & Sarjana & 70 Orang \\
\hline 7 & $\begin{array}{l}\text { Pasca Sarjana } \\
\text { (S2) }\end{array}$ & 3 Orang \\
\hline
\end{tabular}

(Monografi Desa Banjarsari)

Tabel 4 : Jumlah Penduduk Berdasarkan Pekerjaan

\begin{tabular}{|c|l|r|}
\hline No & \multicolumn{1}{|c|}{$\begin{array}{c}\text { Tingkat } \\
\text { Pendidikan }\end{array}$} & Jumlah \\
\hline 1 & PNS & $\begin{array}{r}165 \\
\text { Orang }\end{array}$ \\
\hline 2 & TNI-POLRI & 6 Orang \\
\hline 3 & Wiraswasta & $\begin{array}{r}170 \\
\text { Orang }\end{array}$ \\
\hline 4 & Pertukangan & 23 Orang \\
\hline 5 & Jasa & 14 Orang \\
\hline 6 & Petani & $\begin{array}{r}1.200 \\
\text { Orang }\end{array}$ \\
\hline
\end{tabular}

(Monografi Desa Banjarsari)

Sedangkan jumlah pejabat

pemerintahan desa berdasarkan jenis kelaminnya dapat ditabelkan sebagai berikut :

Tabel 5 : Jumlah Pejabat Pemerintahan Desa Berdasarkan Jenis Kelamin

\begin{tabular}{|c|l|c|c|c|}
\hline \multirow{2}{*}{ No } & \multicolumn{1}{|c|}{ Jabatan } & \multicolumn{3}{|c|}{ Jumlah, Orang } \\
\cline { 3 - 5 } & & L & P & Total \\
\hline 1 & $\begin{array}{l}\text { Pemerintah Desa } \\
\text { a. Kepala Desa } \\
\text { b. Sekretaris Desa } \\
\text { c. Kepala Urusan } \\
\text { d. Kepala Dusun } \\
\text { e. Staf }\end{array}$ & 14 & 0 & 14 \\
\hline 2 & $\begin{array}{l}\text { Badan } \\
\text { Perwakilan Desa } \\
\text { / Baperdes }\end{array}$ & 14 & 1 & 15 \\
\hline 3 & LPKMD & 11 & 2 & 13 \\
\hline
\end{tabular}

\begin{tabular}{|c|c|c|c|c|}
\hline 4 & PKK & 3 & 28 & 28 \\
\hline 5 & $\begin{array}{l}\text { Usaha Ekonomi } \\
\text { Desa }\end{array}$ & 5 & 10 & 15 \\
\hline 6 & $\begin{array}{ll}\text { Ketua } & \text { Rukun } \\
\text { Tetangga } & \\
\end{array}$ & 15 & 3 & 15 \\
\hline 7 & $\begin{array}{ll}\text { Ketua } & \text { Rukun } \\
\text { Warga } & \\
\end{array}$ & 3 & - & 3 \\
\hline 8 & Pengurus RT & 50 & 40 & 90 \\
\hline & Jumlah & 100 & 84 & 184 \\
\hline
\end{tabular}

(Monografi Desa Banjarsari 2007 dan wawancara dengan para pejabat pemerintahan desa)

Organisasi politik atau partai politik yang mempunyai kepengurusan di desa ini sebagaimana tabel di bawah ini :

Tabel 6 : Partai Politik Ranting Desa Banjarsari

\begin{tabular}{|c|l|}
\hline No & \multicolumn{1}{|c|}{ Nama Partai Politik } \\
\hline 1 & Partai Amanat Nasional (PAN) \\
\hline 2 & Partai Golkar (PG) \\
\hline 3 & $\begin{array}{l}\text { Partai Demokrasi Indonesia } \\
\text { Perjuangan (PDIP) }\end{array}$ \\
\hline 4 & Partai Kebangkitan Bangsa (PKB) \\
\hline 5 & Partai Keadilan Sejahtera (PKS) \\
\hline 6 & $\begin{array}{l}\text { Partai Persatuan Pembangunan } \\
\text { (PPP) }\end{array}$ \\
\hline 7 & Partai Demokrat (PD) \\
\hline 8 & Partai Bintang Reformasi (PBR) \\
\hline 9 & $\begin{array}{l}\text { Partai Nasional Banteng } \\
\text { Kemerdekaan (PNBK) }\end{array}$ \\
\hline 10 & Partai Pelopor \\
\hline
\end{tabular}

Sedangkan jumlah organisasi kemasyarakatan non-politik

Tabel 7 : Jumlah Organisasi Masyarakat

\begin{tabular}{|c|l|r|}
\hline No & \multicolumn{1}{|c|}{$\begin{array}{c}\text { Jenis } \\
\text { Organisasi }\end{array}$} & \multicolumn{1}{|c|}{ Jumlah } \\
\hline 1 & \multicolumn{1}{|c|}{3} \\
\hline 1 & $\begin{array}{l}\text { Ormas } \\
\text { /Yayasan }\end{array}$ & 5 Organisasi \\
\hline 2 & $\begin{array}{l}\text { Organisasi } \\
\text { profesi }\end{array}$ & $\begin{array}{r}15 \\
\text { Organisasi }\end{array}$ \\
\hline
\end{tabular}

(Monografi Desa Banjarsari 2007) 


\section{Pemerintahan Desa Banjarsari}

Seiring dengan diberlakukannya

Undang-Undang Nomor 32 Tahun 2004 dan

Peraturan Pemerintah Pengganti Undang-

Undang Nomor 2005 tentang Perubahan

Atas Undang-Undang Nomor 32 Tahun 2004

yang dimaksud tentang Pemerintahan

Daerah Pemerintahan Desa Banjarsari diselenggarakan dengan prinsip-prinsip demokrasi, peran serta masyarakat, pemerataan dan keadilan, serta memperhatikan potensi dan keanekaragaman. Untuk itu pemerintahannya terdiri dari Pemerintah Desa, Badan Perwakilan Rakyat Desa (Baperdes), dan lembaga-lembaga masyarakat yang dibentuk oleh pemerintah desa.

Pemerintah desa dipimpin oleh seorang seorang kepala desa. Dalam menjalankan tugas dan kewajibannya ia dibantu oleh perangkat desa. Perangkat desa terdiri dari seorang sekretaris desa, tiga orang kepala dusun atau kasun (Kasun; Kepel, Bajang, dan Bugangin), tiga orang kepala urusan, tiga modin (modin Kepel, modil Bajang, dan modin Bugangin), dan tiga orang uceng (uceng Kepel, uceng Bajang, dan uceng Bugangin). Pejabat pemerintah desa dipilih oleh rakyat berdasarkan peraturan daerah Kabupaten Madiun.

Dalam menetapkan peraturan desa, kepala desa tidak serta merta dapat memutuskan secara sepihak, karena ada badan permusyawarahan desa yang menampung dan menyalurkan aspirasi masyarakat (berfungsi sebagai badan legislator). Badan tersebut bernama Badan Perwakilan Rakyat Desa yang disingkat dengan Bapaerdes. Badan ini terdiri dari penduduk desa yang dipilih, ditetapkan berdasarkan musyawarah dan mufakat.

Dalam rangka menyukseskan roda pemerintahan desa atau memberdayakan masyarakat, Pemerintah Desa Banjarsari membentuk lembaga-lembaga kemasyarakatan yang ditetapkan dengan peraturan desa dengan berpedoman pada peraturan perundang-undangan yang berlaku. Lembaga kemasyarakatn ini bertugas membantu dan sekaligus sebagai mitra pemerintah desa. Adapun lembagalembaga kemasyarakatan yang dibentuk adalah LPKMD (Lembaga Pemberdayaan dan Kesejahteraan Masyarakat Desa) yang bertugas dalam penyusunan program dan pelaksanaan pembangunan fisik dan non fisik, Posyandu (Pos Pelayanan Terpadu) yang bertugas dalam bidang kesehatan masyarakat desa, PKK yang bertugas dalam memberdayakan kaum perempuan, dan UED (Usaha Ekonomi Desa) yang bertugas dalam menggerakkan perekonomian desa.

Adapun struktur Pemerintahan Desa Banjarsari sebagaimana bagan di bawah ini : 


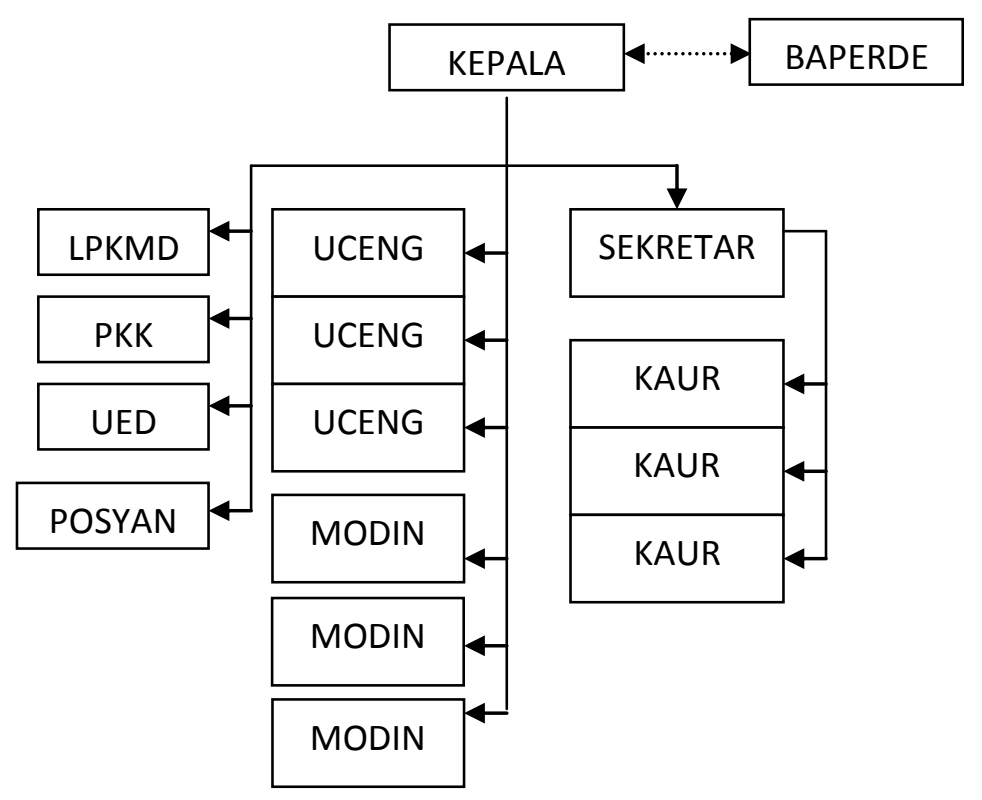

Bagan 2: Struktur Pemerintahan Desa Banjarsari

3. Peran Serta Perempuan Dalam Penyelenggaraan Pemerintahan Desa Banjarsari

Guna mengetahui peran serta perempuan dalam penyelenggaraan pemerintahan desa Banjarsari, maka kajian yang dilakukan tidak lepas dari peran dan posisi perempuan dalam badan atu organisasi yang melaksanakan aktivitas pemerintahan. Hal ini dikarenakan institusi atau lembaga erat kaitannya dengan pranata. Pranata merupakan sistem yang menjadi wahana yang memungkinkan warga masyarakat termasuk kaum perempuan untuk berinteraksi menurut pola-pola resmi atau sistem norma atau aturan-aturan aktivitas masyarakat. Untuk itu titik pandangan kajian ini diarahkan pada institusi pemerinthan desa Banjarsari seperti Pemerintah Desa, Baperdes, LPKMD,
UED, PKK, Posyandu, dan lembaga-lembaga kemasyakatan yang ada.

Selain hal di atas, peran serta kaum perempuan dalam penyelenggaraan Pemerintahan Desa Banjarsari ditunjukkan dalam keterlibatan mereka secara langsung dan tidak langsung dalam pemerintah desa, Baperdes, dan lembaga kemasyarakatan yang dibentuk oleh pemerintah desa. Keterlibat langsung maksudnya, kaum perempuan aktif secara formal sebagai pengurus/atau pejabat dalam pemerintah desa atau lembaga-lembaga desa lainnya. Sedangkan yang tidak secara langsung, maksudnya turut serta dalam penyelenggaraan pemerintahan desa tetapi tidak berada secara permanen dalam struktur pemerintahan desa.

Peran perempuan dalam pemerintah desa dapat dicermati seberapa banyak mereka menduduki jabatan-jabatan dalam pemerintah desa. Saat ini tidak ada perempuan yang menjabat dalam pemerintahan desa Banjarsari. Namun tahun sebelumnya tepatnya pada tahun 1995-2005 desa ini dipimpin oleh seorang perempuan yang bernama Kasilah. Selama kepemimpinannya desa ini berkembang secara baik, pembangunan fisik dan nonfisik sangat dirasakan manfaatnya oleh masyarakat. Menurut Kasilah (57 tahun) ketidakadaan perempuan dalam pemerintah desa disebabkan oleh masih minimnya mentalitas kepemimpinan di kalangan perempuan. Selain hal tersebut menurut 
Israti (59 tahun) kaum perempuan yang mempunyai kepemimpinan relatif banyak kaum berpendidikan dan bekerja sebagai PNS. Hal itu lebih menguntungkan secara ekonomi dibandingkan jabatan dalam pemerintah desa yang waktu masa jabatannya relatif singkat dan urusan, kewajiban dan tanggungjawabnya yang tinggi. Selain itu belum tumbuh kesadaran kritis atas hak-haknya untuk mengaktualisasikan dirinya. Paradigma yang belum banyak bergeser dari soal urusan rumah tangga atau konco wingking.

Baperdes yang yang dipilih oleh, dari, dan untuk rakyat diharapkan mampu mengakomodasi berbagai aspirasi dan kepentingan rakyat. Walaupun dalam proses pembentukkannya dilakukan secara demokratis, namun badan permusyawaran desa atau Baperdes Banjarsari belum banyak diminati oleh kaum perempuan padahal melihat fungsinya tersebut perempuan bisa berbuat banyak sehingga kepentingan terpenuhi. Dari 15 orang anggota Baperdes Banjarsari hanya satu orang yang perempuan.. Dari wawancara yang dilakukan kepada para informan perempuan, sangat kurangnya minat perempuan terhadap Baperdes disebabkan oleh : pertama, belum dipahaminya kelembagaan baru ini di kalangan perempuan, kedua masih begitu kuatnya pengaruh budaya patriarkhi dan ketidaksiapan perempuan untuk menjadi anggota Baperdes.
Walaupun Baperdes sebagian besar laki-laki dan hanya seorang yang perempuan ternyata memberi kontribusi yang positif. Menarik, kalau satu orang saja menunjukkan peran aktif, bagaimana kalau lebih dari seorang. Hal itu ditunjukkan oleh seorang anggota Baperdes yang bernama Sutarmi A.Ma.Pd. (52 tahun) mampu memberi warna dalam perjalanan Baperdes. Menurut Poernomo (66 tahun) yang menjabat ketua Baperdes, Sutarmi, A.Ma.Pd. termasuk aktif dalam mendinamisator badan ini sebagai penyalur aspirasi masyarakat dan mitra kerja pemerintahan desa Banjarsari. Hal tersebut dapat dilihat dari merencanakan dan melaksanakan kebijakan yang mempertimbangan dampaknya bagi perempuan dan laki-laki secara adil. Dengan kata lain kehadiran perempuan dalam Baperdes benar-benar dirasakan eksistensi dan keberadaannya untuk ikut ambil suara, dan bukan hanya diam dan setuju-setuju saja (dalam bahasa kasar orang mengatakan sebagai pelengkap).

Temuan di atas tampak kurang bergaung dan ini diperparah oleh kondisi yang dialami perempuan. Pertemuanpertemuan warga yang membicarakan persoalan yang lingkupnya lebih besar, hanya melibatkan kepala keluarga, yang notabene kaum laki-laki. Contohnya, ketika pemilihan ketua rukun tetangga hanya dihadiri bapak-bapak. Kondisi ini sudah berlangsung lama sehingga menjadikan 
masyarakat, khususnya kaum perempuan, bukan suatu persoalan. Mereka menganggap sudah biasa dan wajar karena bapaklah sebagai kepala keluarga yang lebih pantas untuk membicarakan persoalanpersoalan besar di masyarakat.

Peran perempuan baru mulai sedikit ada gaung dan pengaruhnya pada lembaga-lembaga yang dibentuk oleh pemerintah desa, seperti : LPKMD, PKK, UED, dan Posyandu. Di lembaga-lembaga tersebut kaum perempuan secara kuantitatif dan kualitatif banyak yang terlibat secara aktif. Banyaknya perempuan dalam PKK dan Posyandu sudah pada tempatnya dan jamak, namun bila dilihat dari sepak terjangnya ternyata PKK mempunyai andil yang kuat dalam merancang kebijakan dan pembangunan, khususnya yang dialami perempuan dan anak. Kegiatan ibu-ibu pada forum dasawisma, RT atau PKK lebih padat dan aktif dibandingkan dengan kegiatan bapakbapak. Namun kegiatan-kegiatan PKK belum dimaknai sebagai suatu organisasi yang memiliki nilai tawar dalam penyelenggaraan pememerintahan desa Banjarsari. PKK didominasi oleh kegiatankegiatan yang lebih banyak mengarah pada kegiatan-kegiatan keluarga.

Di lembaga lain yaitu LPKMD dan UED cukup berperan. Hal ini merupakan suatu perlu diapresiasikan walaupun dari segi perimbangan dengan laki-lagi belumlah seimbang atau setidak-tidak sesuai dengan kuota yang 20\%. Di LPKMD ada dua orang perempuan yaitu Sukesi sebagai bendahara dan Hartiningsih sebagai koordinator perempuan. Sedangkan di UED kaum perempuan mendominasi pengurus inti terutama ketua dan bendaharanya dari perempuan, yaitu Iriani Takaria sebagai ketua dan Supini (38 tahun) sebagai bendahara. Banyaknya kaum perempuan yang aktif di lembaga-lembaga ini karena lembaga ini tidak mengikat dengan profesi yang utama mereka jalani, seperti ada yang guru, pegawai pemda, dan lain-lainnya.

Di luar lembaga-lembaga atau badan-badan di atas, ada tokoh-tokoh perempuan yang dijadikan saluran aspirasi masyarakat. Tokoh-tokoh ini tergolong sebagai tokoh informal. Mereka berada dalam lingkup organisasi sosial dan keagamaan, seperti di organisasi perempuan Nahdatul Ulama, takmir masjid, organisasi manula, dan lain-lainnya. Namun untuk organisasi politik atau partai politik sepertinya tidak banyak dilirik oleh kaum perempuan walaupun di desa ini banyak partai politik dan pintu sangat terbuka baginya namun tetap ada terutama di PKS, Partai Golkar dan PKB. Banyak perempuan yang enggan karena lebih banyak waktu mereka untuk bergerak di sektor ekonomi dan terbenturnya pada aturan tentang PNS, TNI-POLRI yang harus cuti atau berhenti dari kedinasannya apabila menjadi pengurus partai politik. 
Percaturan politik di desa Banjarsari sangat dinamis. Ada sepuluh partai politik yang mempunyai kepengurusan di tingkat desa Banjarsari ini, namun hanya ada lima orang yang menjadi pengurus, yaitu tiga orang di Partai Keadilan Sejahtera (PKS) dan dua orang di Partai Kebangkitan Bangsa (PKB). Rendahnya kiprah perempuan dalam panggung politik disebabkab oleh beberapa faktor yaitu : Pertama adalah relasi politik yang timpang antara laki-laki dan perempuan disebabkan oleh sistem politik yang ada sudah terlanjur dikuasai oleh laki-laki. Penguasaan panggung politik oleh laki-laki digunakan untuk memotong jalur politik perempuan melalui berbagai cara. Tatanan politik ditujukan, dipertahankan dan digunakan untuk melanggengkan dominasi politik lakilaki dalam berbagai panggung politik. Partisipasi perempuan dengan sendirinya mengancam posisi politik laki-laki. Berbagai bentuk penyelenggaraan kebijakan dan keputusan ditujukan untuk melanggengkan sistem patriarkhi. Kedua adalah budaya patriarkhi yang masih dominan di kalangan masyarakat pedesaan. Sulit untuk melacak kehadiran budayaan tersebut dalam sejarah umat manusia. Barangkali usianya sama dengan usia peradaban manusia sendiri. Hanya saja berbagai sistem dan nilai yang diciptakan untuk melanggengkan mulai dari ilmu pengetahuan, agama, sampai dengan politik. Sejarah perbedaan gender antara jenis laki-laki dan perempuan terjadi melalui proses yang sangat panjang. Perbedaan-perbedaan gender dikarenakan oleh banyak hal, diantaranya bentuk, disosialisasikan, diperkuat secara sosial dan kultural melalui ajaran keagamaan maupun negara. Ketiga adalah beban kerja perempuan lebih besar dibandingkan dengan laki-laki. Keempat adalah kemauan perempuan untuk terlibat secara aktif dalam aktivitas politik sangat terbatas. Politik dipahami sebagai situasi dan kondisi yang hanya cocok dengan karakter laki-laki. Politik dipandang sebagai persoalan yang "jlimat" bahkan cenderung membahayakan. Keterlibatan perempuan dalam ruang publik bisa mengancam persoalan intern rumah tangga mereka. Berbagai kasus kekerasan fisik muncul sebagai akibat rasa tidak puas laki-laki terhadap aktivitas perempuan di luar rumah tangga yang terlalu intens.

Dari sekian faktor di atas rendahnya partisipasi politik perempuan desa Banjarsari bersumber dari resistensi laki-laki terhadap sikap kritis yang dikembangkan perempuan.

\section{Pembahasan}

Seiring dengan diberlakukannya otonomi daerah di wilayah Kabupaten Madiun, Pemerintahan Desa Banjarsari Kecamatan Madiun diselenggarakan secara lebih demokrasi, tidak ada pembedaan atau diskriminasi terhadap masyarakat, baik 
berdasarkan suku, agama, ras, golongan, usia, maupun jenis kelamin. Namun tidak serta merta dapat meningkatkan peran politik perempuan.

Dari paparan kondisi di atas terlihat, bahwa peran perempuan dalam penyelenggaraan pemerintahan desa kurang signifikan. Ditandai dari masih relatih rendah atau sedikit keterlibatan mereka dalam penyelenggaraan pemerintahan desa. Dapat dicermati apa yang terjadi dalam dinamika lembaga pemerintahan desa, baik pemerintah desa, badan permusyaratan masyarakat atau Baperdes, dan lembaga-lembaga yang dibentuk pemerintah desa memberi peluang bagi perempuan untuk dapat terlibat secara lebih luas dalam pembuatan keputusan. Namun peluang itu belum banyak dimanfaatkan oleh kaum perempuan. Hal itu dikarenakan ; pertama adanya sikap mental yang lemah dan sering menjangkiti suara hati perempuan untuk berbuat maksimal demi masa depannya dan masa depan masyarakatnya. Kurangnya kemauan untuk meningkatkan kualitas diri dengan berbagai aktivitas positif sebagai syarat menjawab tuntutan jaman. Proses ini begitu penting guna membentuk sosok pemimpin yang dapat "mengayomi" dan "mengayemi" masyarakat. Kedua, masih kuatnya budaya patriarki di masyarakat, budaya yang mengukuhkan bahwa laki-laki dipandang sebagai pencari nafkah, sehingga laki-laki begitu dominan perannya dalam proses pengambilan keputusan.

$$
\text { Posisi marginal dengan }
$$

menempatkan perempuan sebagai "konco wingking" menyebabkan perannya hanya pada wilayah domestik semata. Ketiga belum adanya kesadaran kritis dari kebanyakan kaum perempuan sendiri atas hak-haknya untuk mengaktualisasikan diri dan belum banyak perempuan yang berparadigma, bahwa urusan perempuan adalah soal rumah-tangga dan hanya peran skunder. Masalah ini dipengaruhi oleh faktor tingkat pendidikan dan rendahnya kemandirian ekonominya. Hampir sebagian besar perempuan di desa ini berusaha mencari uang sebanyak-banyaknya untuk mencukupi kebutuhan konsumtifnya. Keempat, pemahaman yang keliru dari sebagian masyarakat terhadap perempuan dari faktor religius, perempuan dipandang sebai obyek laki-laki. Dalam persoalan ini orang sering mengatakan dengan istilah adanya interpretasi agama yang kurang tepat. Bagi Allah SWT, laki-laki dan perempuan sama dan sederajat, yang membedakan diantara keduanya adalah ketakwaan saja.

Perempuan yang berperan secara aktif memiliki latar belakang pendidikan dan ekonomi melebihi rata-rata penduduk pada umumnya.dalam masyarakat Desa Banjarsari. Tanpa mengabaikan peran rakyat kecil, kenyataan ini menunjukkan, bahwa individu tidak mungkin dapat 
mengambil langkah-langkah penting yang menyangkut nasib kehidupan orang banyak, apabila individu itu dalam keadaan terbatas dan cenderung kekurangan untuk mengurusi dirinya sendiri. Hal tersebut sejalan dengan yang disampaikan Kartodirdjo (1981) dan Onghokham (1983) bahwa individu-individu yang mapan dan melebihi rata-rata penduduk (elite masyarakat) dapat menentukan dan memainkan peranan penting dalam mewujudkan, mempertahankan, dan mentransformasikan ide/sistem nilai dalam kehidupan masyarakat.

Oleh karena itu perlu upaya keras dan kerja cerdas untuk meningkatkan ekonomi dan penumbuhan kesadaran kritis dari kaum perempuan sendiri atas hakhaknya untuk mengaktualisasikan diri. Kesadaran ini menjadi penting untuk selalu didengungkan agar persoalan perempuan tidak sebatas urusan rumah tangga. Kaum perempuan sesungguhnya mampu berperan banyak baik dalam keluarga maupun masyarakat lebih luas. Selain itu perlu tindakan nyata untuk meningkatkan pemahaman politik dalam arti luas terutama bagi kelompok perempuan ditingkat bawah agar tidak semakin menjauhkan mereka dari proses bernegara atau apolitik. Salah satu caranya yaitu memberdayakan kemandirian organisasi perempuan. Menurut Moore (1998) organisasi ini dapat diklasifikasikan menjadi dua ; 1) organisasi informal yaitu satu bentuk kumpulan "domestik" dimana perempuan bergunjing, bercerita dan melakukan kebajikan misalnya sumbangan-sumbangan amal, 2) organisasi formal misalnya PKK dan dasawisma, organisasi ini walaupun sudah ada belum optimal sensitive-nya terhadap persoalan-persoalan perempuan. Dalam lembaga atau sub-lembaga yang difokuskan untuk memberdayaakan perempuan pedesaan seperti PKK dan UED di atas perlu mengintegrasi berbagai sektor dan multi dimensional. Sebab ketika berbicara mengenai bisnis untuk perempuan, bukan berarti hanya bicara bisnis saja, akan tetapi juga bicara tentang budaya, politik, pendidikan dan lain-lainnya. Aspek yang perlu penekanan adalah memberikan layanan modal, pasar, informasi, serta bantuan teknis yang digunakan sebagai pintu masuk pemberdayaan perempuan.

Selain itu juga adanya tindak lanjutnya perlu adanya peningkatan peran serta perempuan dengan beberapa hal, seperti :

1. Meningkatkan kualitas diri kaum perempuan sendiri dengan berbagai pengetahuan, sejalan dengan perkembangan dan kebijaksanaan pemerintah yang mengarah pada "high tech".

2. Memperkuat partisipasi peran perempuan. Dengan adanya perempuan yang duduk dalam lembaga pemerintahan desa akan ikut menentukan segala kebijaksanaan 
ditingkat "grass root". Untuk lebih menunjukkan peran perempuan yang lebih aspiratif, sehingga perempuan tidak menjadi obyek pembangunan saja.

3. Melibatkan perempuan dalam aktivitas politik agar perempuan tidak terisolasi dalam kehidupan politik. Upaya ini juga berfungsi untuk mendudukan kembali perempuan sebagai warga negara yang untuh.

4. Perlunya sikap arif terbuka dari masyarakat luas khususnya kaum lakilaki untuk bisa menerima perempuan sebagai "partner" kerja atau mitra kerja yang baik.

5. Adanya dukungan dan jaminan pemerintah terhadap kebijakan yang "sensitif gender". Kepastian hukum atau jaminan dari pemerintah ini akan dapat mendukung dan mendorong kaum perempuan untuk lebih bisa berkiprah dan mengaktualisasikan diri dalam berbagai bidang.

\section{Simpulan dan Saran}

\section{Simpulan}

Berdasarkan uraian di muka, maka dapat ditarik kesimpulan, bahwa pemerintahan desa Banjarsari memberi peluang bagi perempuan untuk dapat terlibat secara langsung dan lebih dalam penyelenggaraan pemerintahan desa, namun belum banyak dimanfaatkan oleh kaum perempuan. Hanya 84 orang yang berperan secara aktif dalam lembaga pemerintahan desa dan 10 orang yang menjadi pengurus partai politik dari jumlah perempuan 1.538 orang. Hal itu dikarenakan belum adanya kesadaran kritis dari kebanyakan kaum perempuan sendiri atas hak-haknya untuk mengaktualisasikan diri. Selain itu masih banyak perempuan yang berparadigma, bahwa urusan perempuan adalah soal rumah-tangga dan hanya peran skunder. Politik adalah urusan laki-laki, politik itu kotor, politik itu keras sehingga perempuan tidak perlu ada disana. Pandangan-pandangan seperti inilah yang membuat tidak banyak perempuan yang mau menekuni karir politik atau sekurang-kurangnya terlibat dalam usaha-usaha demi kebaikan bersama. Masalah ini dipengaruhi oleh faktor budaya patriarkhi yang masih dominan, beban kerja perempuan yang lebih besar dibandingkan dengan laki-laki, kemauan untuk terlibat secara aktif dalam aktivitas sangat terbatas, dan tingkat ekonominya. Oleh karena itu perlu proses pemberdayaannya melalui pendidikan, tentu dalam arti yang luas dan pemberdayaan ekonomi desa.

Walaupun begitu, dari sebagian kecil kaum perempuan yang berada dalam lembaga pemerintahan desa dapat memainkan peran yang 
tidak kalang pentingnya bila dibandingkan dengan kaum laki-laki. Melalui Badan Perwakilan Rakyat Desa atau Baperdes (legislatif), partai politik, PKK, UED, LPKMD, kaum perempuan memberi andil dan kontribusi yang sangat berarti dalam merencanakan, melaksanakan, dan mengevaluasi program pemerintahan desa.

\section{Saran}

Sebaiknya perempuan tidak ikut-ikutan mengukuhkan pandangan yang menafikkan peran perempuan di bidang politik dengan menerima begitu saja anggapan yang selalu dilontarkan bahwa politik itu kotor, politik hanya cocok untuk kaum laki-laki, bahwa perempuan tidak boleh jadi pemimpin, dan sebagainya. Untuk itu perlu dan mendesak disempurnakan dan diperluas pendidikan politik bagi perempuan sehingga memahami dan melaksanakan tentang tujuan hidup bersama dan kontribusi apa yang dapat diberikan sebagai bagian dari warga masyarakat desa.

Selain itu juga perlu adanya kesadaran semua pihak secara arif dan bijak, khususnya kaum perempuan menumbuhkan kesadaran kritis atas hak-haknya untuk mengaktualisasikan diri dan memberdayakan kemandirian organisasi perempuan, baik melalui organisasi formal maupun informal.

\section{Daftar Pustaka}

Badudu-Zein.1986. 1986. Kamus Umum Bahasa Indonesia. Jakarta : Balai Pustaka.

Barker, Chrish.2004.Cultural Studies.Yogyakarta : Kreasi Wacana.

Christina dkk.2001.Jaman Daulat Rakyat Dari Otonomi Daerah Ke Demokratisasi. Yogyakarta : Lapera Pustaka Utama

Christina M. 2001. Perempuan dalam Otonomi Daerah dalam Perempuan Dalam Pusaran Demokrasi. Bantul : IP4 Laperra Indonesia.

Fakih, Mansour. 2003. Analisis Gender Dan Tranformasi Sosial. Yogyakarta : Pustaka Pelajar

Fakih, Mansour. 2003. Partisipasi Politik Perempuan Minang Dalam sistem Masyarakat Matrilineal. Padang : LP2EM

Kartodirdjo, Sartono.1981.Elie Dalam Perspektif Sejarah. Jakarta : LP3ES.

Milles, Matthew B dan A Michael Huberman.1992.Analisis Data Kualitatif. Ja-karta : UI Press.

Moore, Henrieta L.1998.Feminisme dan Antropologi Jakarta : Proyek Studi Jender dan Pembangunan FISIP UI dan Penerbit Obor.

Onghokham.1983. Rakyat dan Negara. Jakarta : Sinar Harapan

Pemerintah Desa Banjarsari.2007.Monografi Desa Banjarsari. Madiun : Pemdes Banjarsari

Peraturan Pemerintah Pengangganti Undang Undang Nomor 3 Tahun 2005 Tentang Perubahan Atas UndangUndang Nomor 32 Tahun 2004 Tentang Pemerintahan Daerah.

Sari Murti W.. 2001. Perempuan dan politik Di Era Otonomi Daerah dalam Perempuan Dalam Pusaran Demokrasi. Bantul : IP4 Laperra Indonesia.

Sendratari, Luh Putu.1992. Wanita Dalam Dimensi sejarah Implikasi Dalam Pendidikan Sejarah dalam Aneka Widya. Singaraja : FKIP Universitas Udayana 
Suhartono.2001.Politik lokal, Parlemen Desa: Dari Awal kemerdekaan Sampai Dengan Jaman otonomi Daerah. Yogyakarta : Lapera Pustaka Utama

Tangdilintin, Paulus.1991. Peranan Wanita Konsep Kunci Yang Masih Perlu Definisi, dalam Antarwidya Nomor 3 Tahun 1 Jakarta : PAU-IS-UI.

Tim IP4-Lappera.2001.Perempuan Dalam Pusaran Demokrasi dari Pintu Otonomi Ke Pemberdayaan. Bantul : IP4-Lappera dan The Asia Foundation

Thompson, John B.2004.Kritik Ideologi Global Teori Sosial Kritis Tentang Relasi Ideologi Dan Komunikasi Massa. Yogyakarta : IRCiSoD.

Yam'ah Tsalatsa A. 2001. Dinamika Politik Desa : BPD, Antara Peluang dan Tantangan Bagi Peran Politik Perempuan dalam Perempuan Dalam Pusaran Demokrasi. Bantul : IP4 Laperra Indonesia.

Undang Undang Nomor 22 Tahun 1999 Tentang Pemerintah Daerah.

Undang Undang Nomor 32 Tahun 2004 Tentang Pemerintahan Daerah.

Undang Undang Nomor 39 Tahun 1999

Tentang Hak Azasi Manusia 